\title{
EKSPLORASI BUSANA PESTA COCKTAIL UNTUK REMAJA DENGAN SUMBER IDE TERUMBU KARANG PECTINIA LACTUCA
}

\author{
Wahyu Eka Priana Sukmawaty, M.Pd \\ Desain Busana, Akademi Kesejahteraan Sosial AKK Yogyakarta \\ wahyusukmawaty@gmail.com
}

\begin{abstract}
The study aims to describe cocktail party fashion suitable for young women aged 17-21 with the source of the idea of pectin Lactuca coral reef and describe the adolescent response to the product of exploration of cocktail party fashion with the source of the idea of coral reef Pectinia Lactuca. This research was conducted using descriptive methods. Respondents were taken as many as 30 teenagers in Piyungan Bantul District Yogyakarta aged 17-21 years. Data collection techniques using questionnaires and documentation. Data analysis techniques using descriptive data analysis. The results of this research exploration of fashion products include: the first, based on the results of exploration produced two unique and beautiful cocktail party fashions. For cocktail party fashion the first model consisted of a blouse and a balloon skirt. The balloon skirt was made with the smock technique to give the impression of Pectinia Lactuca coral reef and used brown taffeta fabric and a soft blue draperies blouse to give the impression of the ocean. As for the second model party dress in the form of a mini dress with silhouette $\mathrm{H}$ using obi. On the sleeves and bottom of the dress is given a smock section, while the body part with tie-dye technique is blue. The second result in the form of a teenage response to the first model cocktail party dress with the category of the appropriate use of materials with the design for the first cocktail fashion model can be concluded that $83 \%$ of respondents stated it is appropriate. As for the second cocktail fashion model, it can be concluded that $87 \%$ of respondents stated it is very suitable. For the category of colour conformity with the source of the idea on the first cocktail, the fashion model can be concluded that $90 \%$ of respondents stated it very appropriate. As for the second cocktail fashion model, it can be concluded that $93 \%$ of respondents stated it is very suitable.
\end{abstract}

Keywords:Coctail Party Fashion, Pectinia Lactuca Coral Reef, Teenagers

\begin{abstract}
ABSTRAK
Penelitian ini bertujuan untuk mendeskripsikan busana pesta cocktail yang sesuai untuk remaja putri usia 17-21 tahun dengan sumber ide terumbu karang Pectinia Lactuca; dan mendeskripsikan respon remaja terhadap produk eksplorasi busana pesta cocktail dengan sumber ide terumbu karang Pectinia Lactuca. Penelitian ini dilakukan dengan menggunakan metode deskriptif. Responden yang diambil sebanyak 30 remaja di Kecamatan Piyungan Bantul Yogyakarta yang berusia 17-21 tahun. Teknik pengumpulan data menggunakan angket dan dokumentasi. Teknik analisis data menggunakan analisis data deskriptif. Hasil penelitian eksplorasi produk fashion ini antara lain: yang pertama, berdasarkan hasil eksplorasi menghasilkan dua buah busana pesta cocktail yang unik dan indah. Untuk busana pesta coctail model pertama terdiri blus dan rok balon. Rok balon dibuat dengan teknik smock untuk memberi kesan terumbu karang Pectinia Lactuca dan menggunakan kain tafeeta berwarna cokelat serta blus draperi warna soft blue untuk memberi kesan lautan. Sedangkan untuk busana pesta model kedua berupa mini dress dengan siluet $\mathrm{H}$ menggunakan obi. Pada bagian lengan dan bawah dress diberi bagian smock, sedangkan bagian badan dengan teknik tie-dye berwarna biru. Hasil yang kedua berupa respon remaja terhadap busana pesta cocktail model pertama dengan kategori tingkat kesesuaian penggunaan bahan dengan desain untuk model busana cocktail pertama dapat disimpulkan bahwa 83\% responden yang menyatakan sangat sesuai. Sedangkan untuk model busana cocktail kedua dapat disimpulkan bahwa $87 \%$ responden yang menyatakan sangat sesuai. Untuk kategori tingkat kesesuaian warna dengan sumber ide pada model busana cocktail pertama dapat disimpulkan bahwa 90\% responden yang menyatakan sangat sesuai. Sedangkan untuk model busana cocktail kedua dapat disimpulkan bahwa 93\% responden yang menyatakan sangat sesuai.
\end{abstract}

Kata Kunci: busana pesta cocktail, terumbu karang Pectinia Lactuca, remaja 


\section{PENDAHULUAN}

Busana merupakan salah satu kebutuhan pokok manusia dalam menjalani hidup. Kegunaan busana pada masa sekarang ini sudah mulai begeser dari fungsi utamanya. Dulu busana berfungsi sebagai penutup tubuh, saat ini fungsi pakaian lebih dari sekedar penutup tubuh, namun juga sebagai sarana bergaya dan mengikuti perkembangan jaman. Terlebih lagi saat ini perkembangan industry mode dan fashion di Negara-negara besar seperti Paris, New York, Korea sudah mulai mempengaruhi penggunaan busana yang ada di Indonesia.

Kebutuhan akan penggunaan busana pada saat ini sudah mulai digunakan oleh lapisan umur remaja. Remaja dalam perkembangannya merupakan fase dimana sudah mulai berkembang dari anak-anak menuju dewasa. Sehingga pada masa-masa remaja, perncarian akan jati diri merupakan sebuah keinginan yang harus dicapai oleh remaja. Mereka mencari jati diri dengan cara mencoba menggunakan halhal baru yang dapat mereka coba dan hal yang membuat mereka tertarik. Busana menjadi salah satu cara para remaja untuk mencari identitas dan jati diri mereka. Dengan menggunakan dan mengikuti perkembangan berbusana para remaja menganggap bahwa mereka memperluas dan dapat mendongkrak popularitas diantara lingkungan pertemanannya. Masa remaja atau masa puber tidak ada bedanya dengan masamasa lain dalam rentang kehidupan, anak dianggap dewasa apabila sudah mampu mengadakan reproduksi (Hartini, 2017).

Lebih lanjut, fase remaja terbagi atas 3 antara lain: fase awal masa remaja usia 10-14 tahun, fase masa remaja tengah usia 14-17 tahun, dan fase akhir masa remaja usia 17-21 tahun (Hartini, 2017). Setiap fase memiliki karakteristik sendirisendiri. Pada penelitian ini difokuskan pada fase remaja akhir, yang memiliki karakteristik selalu ingin berekplorasi dalam penampilan sehingga berpeluang untuk menjadi konsumen dengan desain-desain busana yang aktraktif. Selain itu, penggunaan busana untuk berbagai kesempatan waktu sangat diperhatikan oleh fase remaja akhir ini. Kesempatan berbusana yang paling sering diperhatikan oleh remaja akhir yakni kesempatan pesta, khususnya busana pesta cocktail.

Busana pesta adalah busana yang dipakai wanita untuk menghadiri pesta atau acara resmi pada malam hari. Biasanya untuk acara formal berlengan tertutup sehingga kelihatan rapi dan sopan tetapi tetap terlihat mewah (Harsono, 2019). Bahan yang digunakan lebih bagus, jahitan yang halus, desain dan hiasan yang menarik (Kurniawati, 2017).

Penggolongan busana pesta berdasarkan waktu ada tiga yakni pagi, sore, dan malam. Busana pesta pagi adalah busana pesta yang dikenakan pada kesempatan pagi hari antara pukul 09.0015.00. Busana pesta sore adalah busana pesta yang dipakai pada kesempatan sore hari menjelang malam. Busana pesta malam adalah 
busana yang dipakai pada kesempatan pesta dari waktu matahari terbenam sampai waktu berangkat tidur (Alifah, 2018). Karena pada pembahasan kali ini mengenai busana cocktail, maka termasuk dalam busana pesta sore.

Pada tahun 1920-an, para wanita Amerika terus mencapai kemandirian yang lebih besar. Banyak yang memilih untuk terus bekerja. Gaya feminim dari zaman Edwardian mulai ditinggalkan. Wanita lebih berani menonjolkan gaya rambutnya dan mengenakan lipstik, perona pipi, dan maskara (Hill, 2004). Pada tahun tersebut memunculkan fenomena baru dari kebiasaan perempuan yang berani menikmati cocktail di soirées dan lounge. Acara pesta cocktail umumnya berlangsung antara jam enam dan delapan malam untuk elit modis progresif (Elyssa da Cruz, 2004).

Para wanita menggunakan gaun yang identic dengan panjang gaun dibawah lutut. Busana cocktail berlengan panjang, garis leher sederhana, dan aksesoris yang sederhana untuk siang hari. Pada malam hari busana coctail menjadi berbeda dengan tampilan lebih ekslusive dengan bahan dari sutra, failles atau satin. Sering kali satu- satunya perbedaan antara busana harian dan busana cocktail adalah kain Noir dan topi cocktail bentuk Cloche, yang dihiasi dengan bulu, batuan berkilau/diamond, dan manik-manik bordir yang menunjukkan estetika yang lebih formal. Sarung tangan pendek dipakai secara universal untuk pakaian cocktail dan dapat ditemukan dalam banyak warna, meskipun putih dan hitam merupakan warna yang paling popular pada saat itu (Steele, 2005).

Pada tahun 1947, Christian Dior membuat busana cocktail dengan tampilan lebih feminim, garis pinggang jelas, dan panjang gaun sampai pertengahan betis serta menggunakan sarung tangan dan topi berbulu (Arnold, 2001). Dari sejarah busana cocktail diatas dapat disimpulkan bahwa busana cocktail adalah busana yang digunakan pada kesempatan pesta setelah bekerja dengan tampilan busana yang berupa gaun panjang sebetis, aksesoris sederhana, menggunakan topi dan sarung tangan.

Begitu halnya dengan yang diutarakan oleh Alifah bahwa busana cocktail yaitu busana pesta setengah resmi dengan memperhatikan model, panjang dan warnanya. Panjang busana pesta cocktail biasanya di atas lutut sampai dibawah lutut $10 \mathrm{~cm}$ dengan warna-warna yang terang sehingga cocok untuk digunakan untuk remaja (Alifah, 2018). Untuk itu, karena busana pesta cocktail remaja memiliki karakteristik tersendiri maka perlu dilakukan eksplorasi untuk menghasilkan busana yang indah.

Eksplorasi pada busana mendorong munculnya variasi teknik dalam pengolahan kain di masyarakat, antara lain adalah teknik manipulating fabric atau rekayasa bahan tekstil yang merupakan suatu teknik menghias kain dengan memanfaatkan beberapa macam teknik 
dekoratif pada permukaan kain maupun pada struktur kain tersebut (Utami, 2018). Dua diantara teknik manipulating fabric yang telah banyak dipraktekkan yaitu smock dan tie dye (ikat celup). Kedua Teknik manipulating fabric ini apabila diterapkan dengan tepat akan membuat busana menjadi lebih indah dan aktraktif.

Smock merupakan salah satu teknik keterampilan menjahit dan menyulam tangan, yaitu teknik tusukan menjahit untuk membuat kerutankerutan yang menghasilkan motif menarik, sesuai pola tertentu (Ristiani \& Irianti Nugrahani,2014).

Biasanya bahan yang yang telah diberi motif smock dapat langsung dibuat untuk berbagai jenis produk misalnya baju, tas, sarung bantal, selop dan lain sebagainya. Proses membuat smock relative cepat dan mudah. Bentuk manipulating fabric lainnya yaitu tie dye. Tie dye adalah proses pembuatan motif di atas kain dengan melakukan pengikatan untuk merintangi warna. (Wardoyo \& Suryo Tri Widodo, 2018).

Keunikan tie-dye dibanding dengan kerajinan tekstil lainnya adalah terletak pada teknik pembuatannya yang cukup sederhana guna menghasilkan sebuah motif di atas kain secara cepat dan mudah. Tie-dye jauh lebih mudah dipelajari daripada batik dan mengalami perkembangan yang cukup baik dalam dunia manipulating fabric secara umum. Proses pembuatan tie-dye menurut (Gausa, 2015) yakni desain terikat paling sederhana dibuat dengan menarik bagian kain secara interval, atau mengikat kain. Kemudian bagian yang diikat tersebut di lepas setelah pencelupan sehingga menciptakan pola lingkaran. Penggunaan bijibijian atau kerikil diikat ke dalam kain untuk membuat pola sehingga menimbulkan beberapa kesan artistik ketika akan dijahit.

Salah satu kekhasan yang juga dimiliki oleh tie-dye adalah terletak pada motif yang dihasilkannya, seringkali memunculkan berbagai efek secara tidak terduga dan kadang-kadang tidak bisa diulangi lagi walaupun mempergunakan teknik dan cara yang sama. Inilah yang menjadikan keteknikan dalam tie-dye selalu berkembang dan sangat potensial untuk terus dikembangkan serta digali secara terus menerus tanpa mengenal batas dari keteknikan dasar yang sudah ada dan lazim digunakan sebelumnya.

Pada pembuatan busana pesta cocktail untuk remaja, akan mengambil sumber ide sumber ide terumbu karang Pectinia Lactuca. Tujuannya yaitu agar busana yang dibuat lebih bermakna dan mempunyai tema, sehingga secara totally look akan lebih menarik dan bemilai jual. Busana ini juga diharapkan dapat menjadi inspirasi para remaja.

Terumbu karang Pectinia Lactuca, jenis ini mempunyai ciri-ciri hidup berkoloni submasif, mereka membentuk dinding-dinding dengan tinggi yang relatif seragam. Kebanyakan dapat dilihat dari koloni di tengah sampai pinggir. Warna dari terumbu karang ini berwarna keabu- 
abuan, hijau dan coklat (Agustina et al., 2016). Sepintas karang ini mirip dengan P.maxima dan P. ayleni. Terumbu karang Pectinia Lactuca tersebar dari Perairan Indonesia, Philipina, Papua New Guinea dan Australia. Terumbu karang ini umumnya banyak hidup di perairan dangkal dan berarus deras.

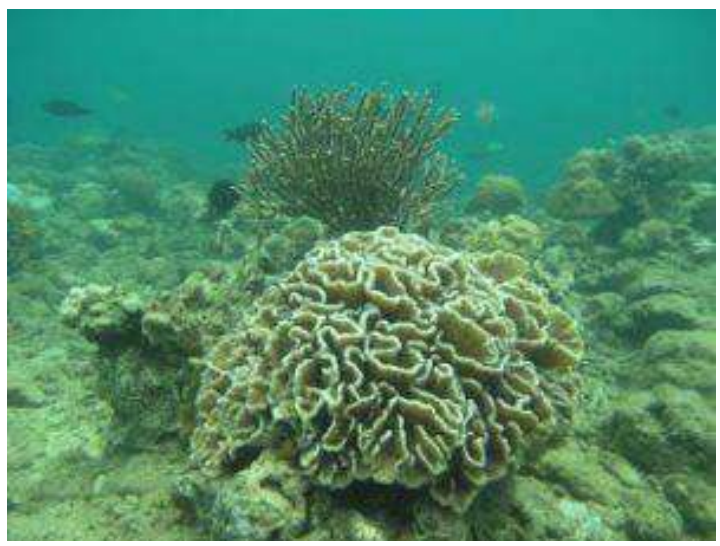

Gambar 1. Terumbu Karang Pectinia Lactuca (sumber: https://ilmugeografi.com/ilmu-bumi/laut/ terumbu- karang)

Dari penjelasan singkat mengenai terumbu karang Pectinia Lactuca diatas, akan diambil bentuk dasar dari terumbu karang tersebut kemudian dieksplore menjadi busana pesta coctail melalui teknik smock. Selain itu untuk memenuhi efek dari habitat terumbu karang yakni lautan, kain yang digunakan untuk membuat busana pesta coctail akan di olah terlebih dahulu dengan teknik tie dye. Oleh karena itu, timbul pertanyaan bagaimanakah bentuk busana pesta coctail untuk remaja putri usia 17-21 tahun dan bagaimana respon remaja terhadap pembuatan busana pesta cocktail dengan sumber ide terumbu karang Pectinia Lactuca.

\section{METODE}

Penelitian ini merupakan penelitian deskriptif. Subyek penelitian yakni remaja akhir di kecamatan Piyungan Bantul Yogyakarta yang berjumlah 30 orang dengan rentan usia 17 21 tahun. Dan berjenis kelamin perempuan. Teknik pengumpulan data yang digunakan yaitu melalui angket dan dokumentasi digunakan untuk mngukur respon remaja terhadap busana pesta cocktail yang dibuat. Teknik analisis data menggunakan analisis data deskriptif.

\section{HASIL DAN PEMBAHASAN PENELITIAN}

\section{Hasil Penelitian}

Berdasarkan hasil penelitian eksplorasi busana pesta cocktail untuk remaja dengan sumber ide terumbu karang Pectinia Lactuca maka diperoleh dua buah desain busana pesta cocktail untuk remaja dengan bentuk desain yang unik. Untuk desain yang pertama terdiri dari blus dan rok balon. Rok balon dibuat dengan teknik smock untuk memberi kesan terumbu karang Pectinia Lactuca dan menggunakan kain tafeeta berwarna cokelat dan blus draperi warna soft blue untuk memberi kesan lautan. Sedangkan untuk desain busana pesta cocktail yang kedua berupa mini dress dengan siluet $\mathrm{H}$ dengan obi. Pada bagian lengan dan bawah dress diberi bagian smock, sedangkan bagian badan dengan teknik tie dye berwarna biru. Kemudian dari desain busana pesta cocktail tersebut dilakukan proses produksi dan proses finishing hingga tahap penyelesaian berwujud busana siap pakai seperti dibawah ini: 
Hasil penelitian ini didasarkan pada hasil penyebaran angket dalam bentuk skala likert dengan kategori antara lain: sangat sesuai, sesuai, kurang sesuai, dan tidak sesuai. Pengambilan data dilakukan pada 30 remaja berusia 17-21 tahun di kecamatan Piyungan Yogyakarta dengan berdasarkan dua tinjauan yaitu kesesuaian penggunaan bahan dengan desain; dan kesesuaian warna dengan sumber ide kemudian ditampilkan pada bentuk diagram dibawah ini:
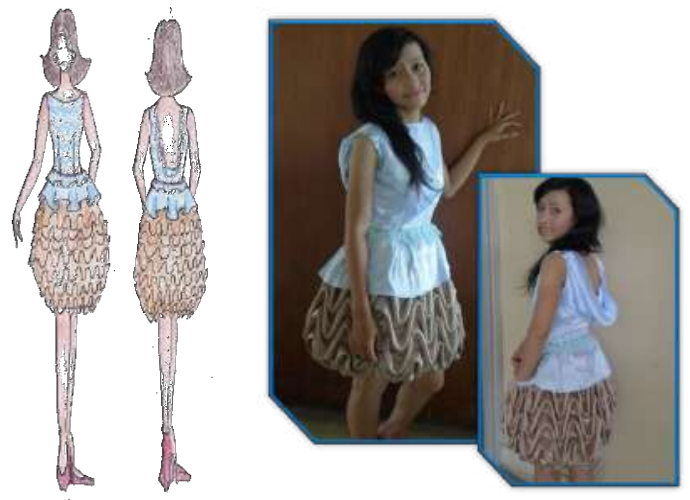

Gambar 2. Desain dan Hasil Busana Pesta Cocktail Model Pertama Tampak Muka dan Belakang.

Sumber: Data Pribadi

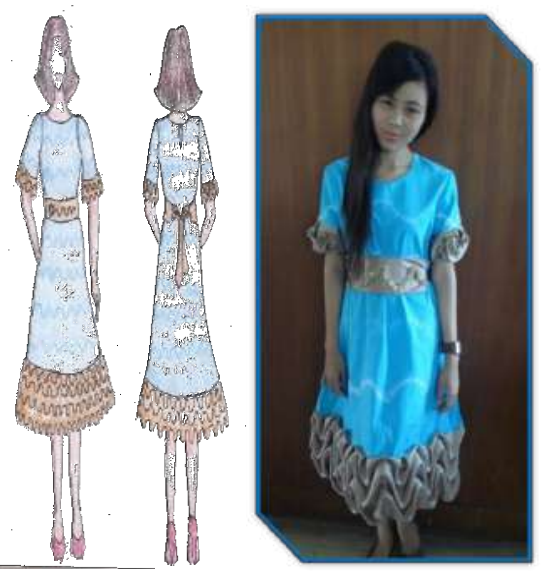

Gambar 3. Desain dan Hasil Busana Pesta Cocktail Model Kedua Tampak Muka dan Belakang. Sumber : Data Pribadi

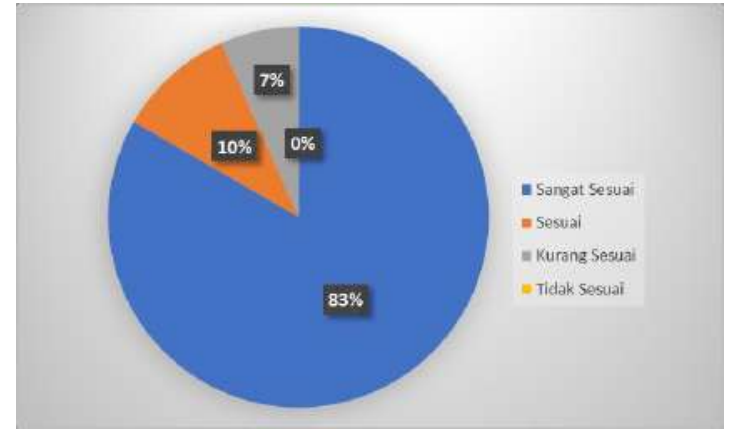

Gambar 4.Diagram Tingkat Kesesuaian Penggunaan Bahan Dengan Desain untuk Model Pertama Busana Pesta Cocktail Remaja

Dari gambar diagram diatas, dapat dinyatakan bahwa tingkat kesesuaian penggunaan bahan dengan desain untuk model pertama busana pesta cocktail remaja dapat disimpulkan bahwa $83 \%$ responden yang menyatakan sangat sesuai, $10 \%$ responden yang menyatakan sesuai, dan $7 \%$ responden yang menyatakan kurang sesuai. Selanjutnya akan digambarkan dalam diagram tingkat kesesuaian untuk model yang kedua sebagai berikut ini:

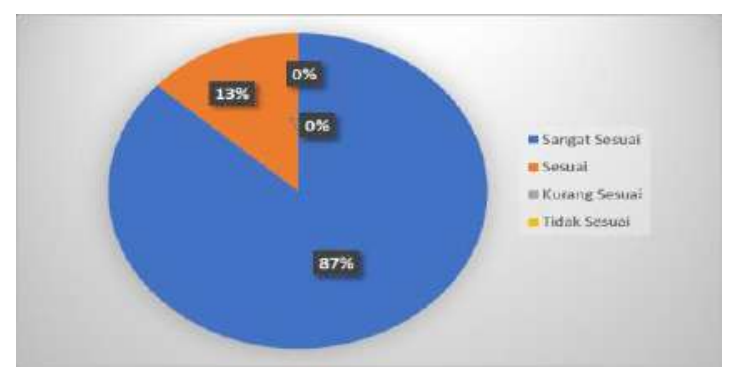

Gambar 5. Diagram Tingkat Kesesuaian Penggunaan Bahan Dengan Desain untuk Model Kedua Busana Pesta Cocktail Remaja

Dari gambar diagram diatas, dapat dinyatakan bahwa tingkat kesesuaian penggunaan bahan dengan desain untuk model kedua busana pesta 
cocktail remaja dapat disimpulkan bahwa $87 \%$ responden yang menyatakan sangat sesuai, dan $13 \%$ responden yang menyatakan sesuai.

Dengan demikian untuk kategori tingkat kesesuaian penggunaan bahan dengan desain terdapat selisih $5 \%$ lebih besar memilih model busana cocktail yang kedua yang tingkat kesesuaiannya bahan lebih besar.

Selanjutnya akan ditampilkan diagram untuk mengukur tingkat kesesuaian warna dengan sumber ide sebagai berikut ini:

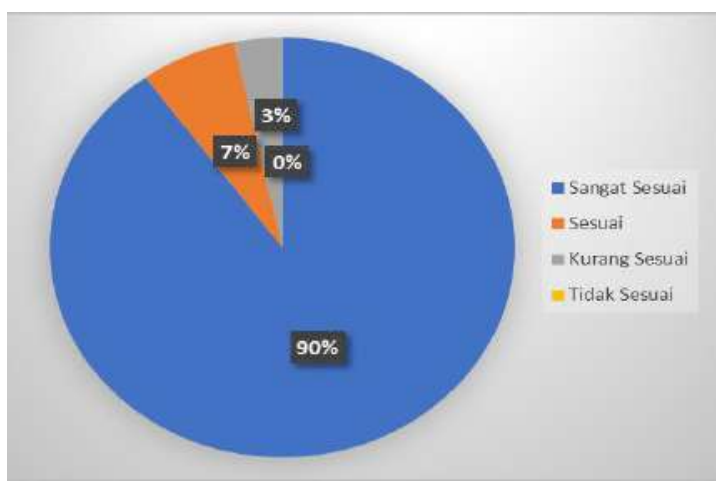

Gambar 6. Diagram Tingkat Tingkat Kesesuaian Warna dengan Sumber Ide untuk Model Pertama Busana Pesta Cocktail Remaja

Dari Dari gambar diagram diatas, dapat dinyatakan bahwa tingkat kesesuaian warna dengan sumber ide untuk model busana cocktail pertama dapat disimpulkan bahwa 90\% responden yang menyatakan sangat sesuai, $7 \%$ responden yang menyatakan sesuai, dan $3 \%$ responden yang menyatakan kurang sesuai. Selanjutnya akan digambarkan dalam diagram tingkat kesesuaian untuk model yang kedua sebagai berikut:

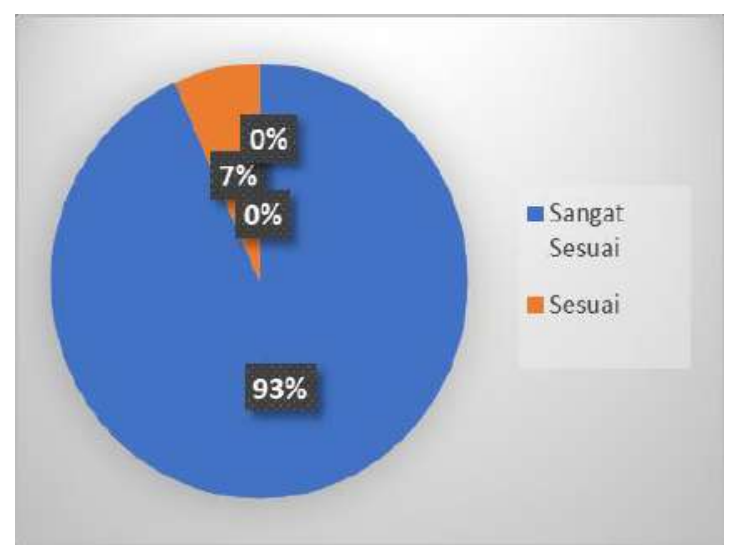

Gambar 7. Diagram Tingkat Tingkat Kesesuaian Warna dengan Sumber Ide untuk Model Kedua Busana Pesta Cocktail Remaja

Dari Dari gambar diagram diatas, dapat dinyatakan bahwa tingkat kesesuaian warna dengan sumber ide untuk model busana cocktail kedua dapat disimpulkan bahwa 93\% responden yang menyatakan sangat sesuai, $7 \%$ responden yang menyatakan sesuai. Tahap selanjutnya yakni pembahasan penelitian sebagai berikut:

\section{Pembahasan Penelitian}

Pada eksplorasi busana pesta cocktail untuk remaja dengan sumber ide terumbu karang Pectinia Lactuca, ada beberapa tahapan yang dilakukan antara lain:

\section{Tahapan Mendesain.}

Pada tahapan ini dibuat desain busana pesta cocktail untuk remaja yang unik dan sesuai dengan sumber ide terumbu karang pectinia lactuca. Tahapan ini dimulai dari design sketching dan presentation drawing. Tujuannya agar proses pembuatan busana pesta dapat lebih terarah dan sesuai dengan sumber ide. 
Menurut (Agustina et al., 2016), Bentuk terumbu karang pectinia lactuca yang mempunyai ciri-ciri berkoloni submasif, mereka membentuk dindingdinding dengan tinggi yang relatif seragam. Kebanyakan dapat dilihat dari koloni di tengah sampai pinggir. Warna dari terumbu karang ini berwarna keabu-abuan, hijau dan coklat.

Pada design sketching untuk model pertama diwujudkan yaitu berupa rok balon yang dibentuk dengan teknik smock. Untuk mendapatkan kesan terumbu karang pectinia lactuca menggunakan bahan tafeeta dan berwarna cokelat. Sedangkan untuk blus, dengan bentuk garis leher tampak depan berbentuk Sabrina dan bentuk garis leher tampak belakang berbentuk draperi untuk mendapatkan kesan lautan.

Model busana kedua berupa dress berbentuk siluet $\mathrm{H}$ dan sesuai dengan yang diutarakan (Alifah, 2018) bahwa panjang busana pesta cocktail biasanya di atas lutut sampai dibawah lutut 10 $\mathrm{cm}$ dengan warna-warna yang terang sehingga cocok untuk digunakan untuk remaja maka pada design sketching model kedua panjang busana 10 $\mathrm{cm}$ dibawah lutut.

Perwujudan terumbu karang pectinia lactuca diletakkan pada bagian bawah rok dan lengan bawah. Untuk mendapatkan kesan lautan, maka dress didesain berwarna biru. Untuk lebih jelasnya terkait design sketching busana pesta cocktail dari model pertama dan model kedua ditampilkan pada gambar dibawah ini:

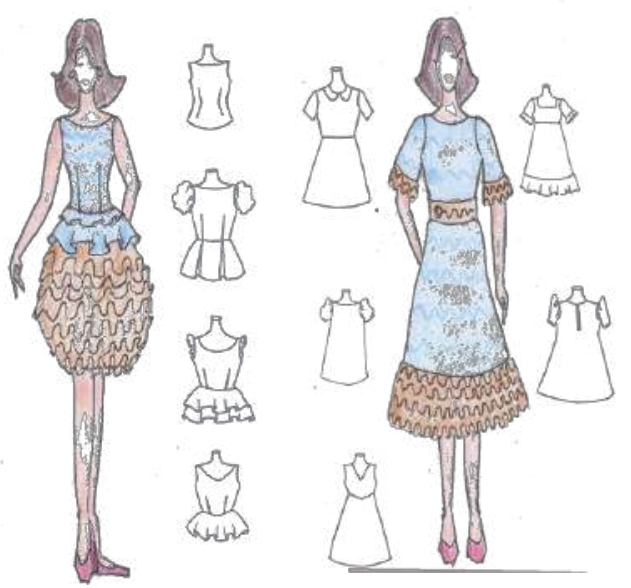

Gambar 8. Design Sketching Busana Pesta Cocktail Remaja Model Pertama dan Kedua Sumber : Data Pribadi

Langkah selanjutnya setelah proses design sketching busana yakni proses pembuatan presentation drawing tujuannya untuk mengetahui setiap detail dari busana yang akan dibuat. Berikut ini proses pembuatan presentation drawing model pertama dan kedua:

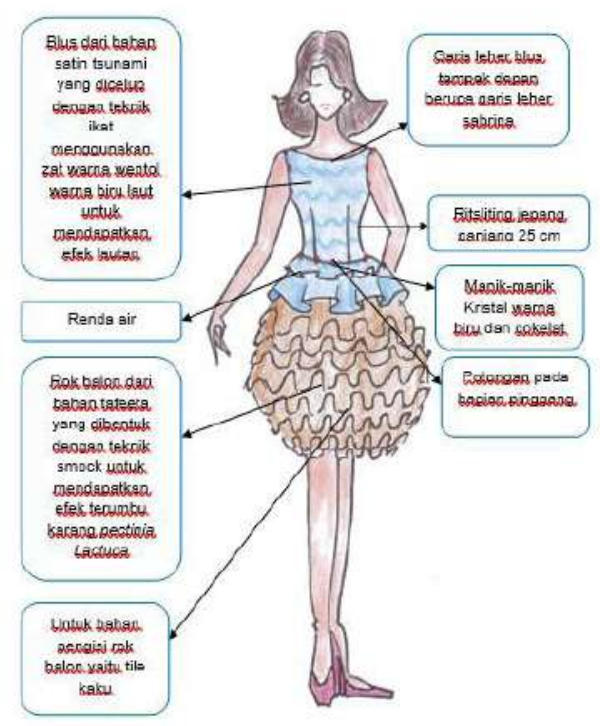




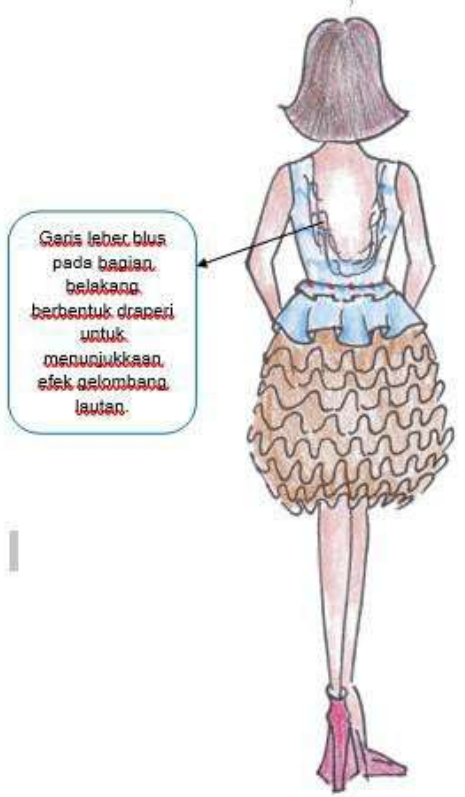

Gambar 9. Presentation Drawing Busana Pesta Cocktail Remaja Model Pertama Sumber : Data Pribadi

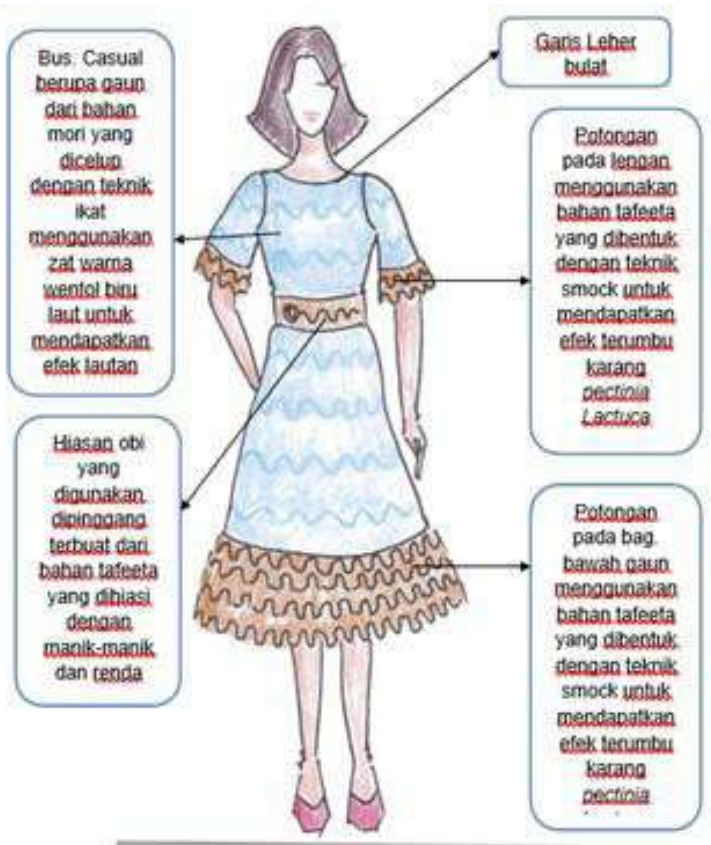

Gambar 10. Presentation Drawing Busana Pesta Cocktail Remaja Model Kedua. Sumber : Data Pribadi

\section{Tahapan Manipulating Fabric.}

Pada tahapan ini dilakukan pemilihan bahan dan pengolahan bahan yang sesuai dengan busana pesta cocktail. Pemilihan bahan untuk busana pesta cocktail model pertama terdiri bahan utama untuk blus menggunakan kain satin dan untuk rok menggunakan kain tafeeta. Bahan lining untuk busana pesta menggunakan asahi. Bahan interlining menggunakan tile kaku yang dijahit pada rok balon sebagai pengisi. Bahan facing menggunakan fiselin kodok.

Pemilihan bahan tekstil untukbusana pesta cocktail model kedua dimulai dari pemilihan bahan utama yang menggunakan kain katun mori dan kain tafeeta. Bahan lining menggunakan kain ero. Bahan facing menggunakan fiselin kodok.

Selanjutnya dilakukan proses tie-dye untuk mendapatkan kesan lautan yang diterapkan pada kain satun dan kain katun untuk busana pesta cocktail. Proses tie-dye menggunakan zat warna wentol. Langkah-langkah proses pembuatannya dimulai dengan menyediakan zat warna wentol blue. Selanjutya pembuatan motif ombak pada kain satin dan katun dengan menjelujur.

Setelah mtif dijelujur langkah selanjutnya yakni pengikatan kain dan perendaman kain pada TRO yang berfungsi untuk memudahkan kain menyerap warna. Setelah kain dicelup TRO, kain dimasukkan ke dalam air mendidih yang berisi pewarna wentol selama \pm 30 menit. Setelah pewarna kain menyerap, kain dicuci 
menggunakan air dingin dan pengikat kain dilepas. Kemudian kain diangin-anginkan ditempat yang teduh.

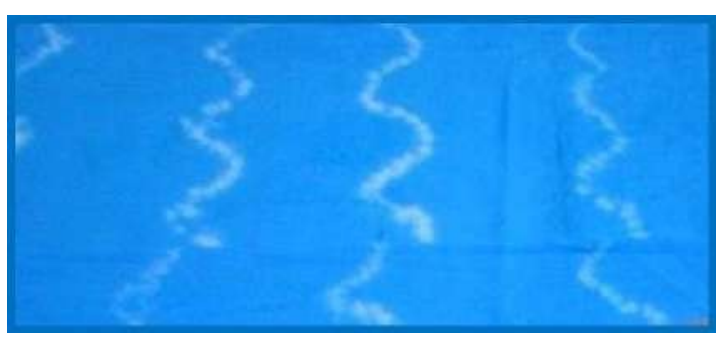

Gambar 11. Hasil dari Tie- Dye.

Teknik manipulating fabric yang selanjutnya yakni teknik smock yang diterapkan pad kain tafeeta untuk mendapatkan bentuk dasar dari terumbu karang Pectinia Lactuca. Langkah-langkah pembuatan teknik smock yaitu membuat garis kotak-kotak dengan ukuran $5 \times 5 \mathrm{~cm}$. tentukan arah jelujur yang akan dilalui benang untuk menarik agar mendapatkan efek gelombang seperti terumbu karang. Berikut ini wujud dari teknik smock yang dibuat:
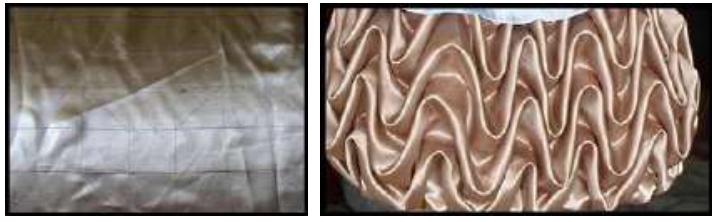

Gambar 12. Proses dan Hasil Smock. Sumber : Data Pribadi

\section{Tahapan Membuat Pola dan Menjahit.}

Pada tahapan ini pola dasar yang digunakan adalah pola konstruksi. Pola konstruksi adalah pola konstruksi adalah pola dasar yang dibuat berdasarkan ukuran badan sipemakai, dan di gambar dengan perhitungan secara matematika sesuai dengan sistem pola konstruksi (Lindqvist dalam (St Aisyah, 2017)). Pola konstruksi yang digunakan yakni system SO-EN. Ukuran menggunakan ukuran standar.
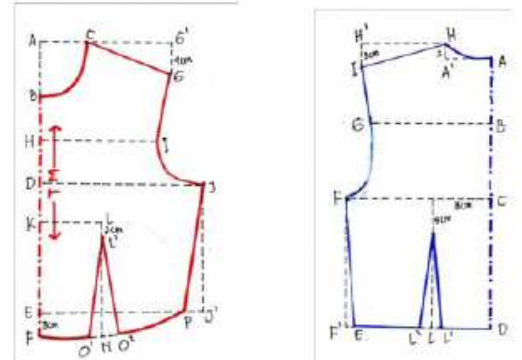

Gambar 13. Pola Dasar Sistem SO-En.

Dari pola dasar yang telah dibuat kemudian dilakukan pecah pola. Pecah pola adalah proses mengubah pola dasar menjadi pola yang sesuai dengan model busana. Caranya antara lain dengan memindahkan lipit, memotong, menyambung, atau memanjangkan dan memendekkan (menambah atau mengurangi ukuran) pada bagian-bagian tertentu pada pola dasar. (Pratiwi dalam (St Aisyah, 2017). Untuk pecah pola busana pesta cocktail model pertama pada penelitian ini sebagai berikut:

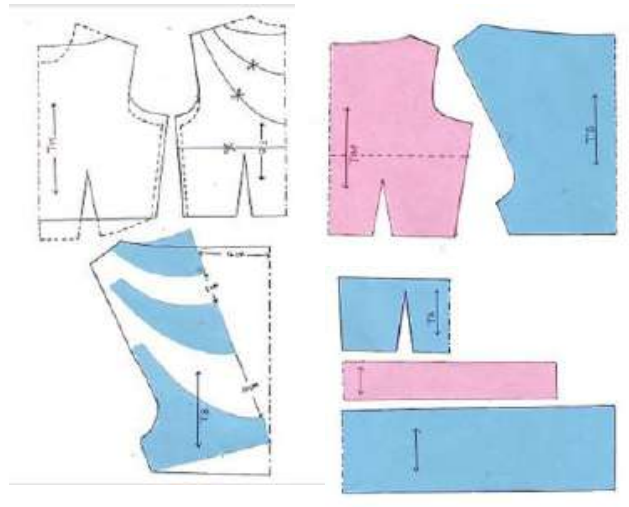

Gambar 14. Hasil dari Pecah Pola Busana Pesta Cocktail Remaja Model Pertama . 
Untuk pola busana pesta cocktail remaja model kedua menggunakan ukuran standar sehingga pecah pola yang dilakukan menghasilkan pola sebagai berikut:

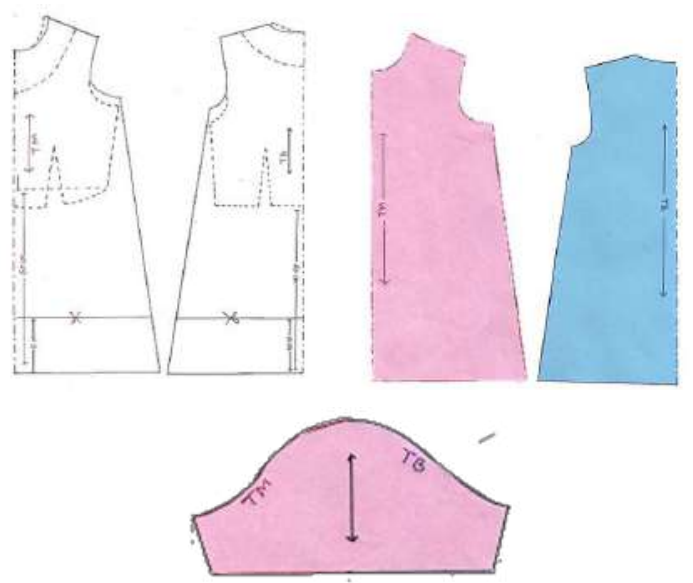

Gambar 14. Hasil dari Pecah Pola Busana Pesta Cocktail Model Kedua.

Setelah membuat pola dasar dan membuat pecah pola, tahapan selanjutnya yakni proses menjahit. Yang pertama kali dijahit yakni busana pesta cocktail model pertama. Adapun langkahlangkah untuk menjahit busana pesta coctail desain pertama ini yang terdiri dari blus dan rok balon yang dismock antara lain:

Menjahit Blus Pesta. langkah menjahitnya antara lain: (a) jahitlah kupnat pada bag.tengah muka dan tengah belakang bahan utama; (b) jahitlah kupnat pada bag.tengah muka dan tengah belakang bahan lining; (c) menjahit bag.bahu pada bahan utama; (d) menjahit bagian sisi sebelah kiri bahan utama; $(e)$ memasang ritsliting jepang pada sisi bagian kanan bahan utama; (f)setelah memasang ritsliting, bagian atas blus disambung dengan bagian bawah blus; (g)menyambung bahan utama dengan bahan lining; (h) memasang rompok pada bagian kerung lengan; (i) menjahit renda air pada bagian sambungan pinggang blus; (j)mengesum bahan lining dengan bahan utama blus.

Menjahit rok balon. langkah menjahitnya antara lain: (a)menyambung bagian sisi rok; (b)menjahit bahan utama dan bahan lining pada bagian bawh rok; (c) menjahit bahan interlining yang berupa tile kaku pada bagian buruk; (d) kemudian menjahit kerut bagian atas rok bahan utama dan bahan lining secara bersama-sama; dan (e) memasang ban pinggang pada bagian atas rok.

Busana pesta cocktail model kedua. Langkahlangkah untuk menjahit busana pesta cocktail model kedua antara lain: (a) menyambung bagian bahu dan bagian sisi gaun; (b) menyambung bagian bawah gaun dengan kain yang telah dibentuk dengan teknik smock; (c) menyambung bahan utama dan bahan lining; (d)memasang lengan; (e)pada bagian buruk penyelesaian lengan dengan cara di rompok; dan (g)memasang kancing pada bagian belakang gaun.

\section{Tahapan Penyimpanan.}

Setelah proses menjahit, ada satu tahapan lagi yang tidak kalah penting yakni teknik penyimpanan produk busana pesta cocktail. Busana disimpan dengan cara dihanger. Sebelum dihanger sebaiknya di seterika yang rapi. Pada saat diseterika sebaiknya tidak diberi pelicin/pengharum pakaian karena akan 
merusak pewarnaan kain. Khusus untuk rok balon sebaiknya di seterika dari bagian buruk/dalam rok.

\section{Hasil Analisis Data.}

Adapun respon remaja terhadap kedua busana pesta cocktail untuk remaja dengan sumber ide terumbu karang Pectinia Lactuca berdasarkan hasil penyebaran angket didapatkan hasil bahwa bahwa:

Tingkat kesesuaian penggunaan bahan dengan desain untuk model busana cocktail pertama dapat disimpulkan bahwa $83 \%$ responden yang menyatakan sangat sesuai, $10 \%$ responden yang menyatakan sesuai, dan $7 \%$ responden yang menyatakan kurang sesuai.

Tingkat kesesuaian penggunaan bahan dengan desain untuk model busana cocktail kedua dapat disimpulkan bahwa $87 \%$ responden yang menyatakan sangat sesuai, dan $13 \%$ responden yang menyatakan sesuai. Dengan demikian untuk kategori tingkat kesesuaian penggunaan bahan dengan desain terdapat selisih $5 \%$ lebih besar memilih model busana cocktail yang kedua yang tingkat kesesuaiannya bahan lebih besar.

Tingkat kesesuaian warna dengan sumber ide untuk model busana cocktail pertama dapat disimpulkan bahwa $90 \%$ responden yang menyatakan sangat sesuai, $7 \%$ responden yang menyatakan sesuai, dan $3 \%$ responden yang menyatakan kurang sesuai.

Tingkat kesesuaian warna dengan sumber ide untuk model busana cocktail kedua dapat disimpulkan bahwa 93\% responden yang menyatakan sangat sesuai, $7 \%$ responden yang menyatakan sesuai.

\section{KESIMPULAN}

Hasil eksplorasi busana pesta cocktail untuk remaja dengan sumber ide terumbu karang Pectinia Lactuca menghasilkan dua buah busana yang unik dan indah. Untuk busana pesta model pertama terdiri blus dan rok balon. Rok balon dibuat dengan teknik smock untuk memberi kesan terumbu karang Pectinia Lactuca dengan menggunakan kain tafeeta berwarna cokelat dan blus draperi warna soft blue untuk memberi kesan lautan.

Sedangkan untuk busana pesta model kedua berupa mini dress dengan siluet $\mathrm{H}$ dengan obi. Pada bagian lengan dan bawah dress diberi bagian smock, sedangkan bagian badan dengan teknik tie-dye berwarna biru.

Respon remaja terhadap busana pesta cocktail model pertama dengan kategori tingkat kesesuaian penggunaan bahan dengan desain untuk model busana cocktail pertama dapat disimpulkan bahwa 83\% responden yang menyatakan sangat sesuai, $10 \%$ responden yang menyatakan sesuai, dan $7 \%$ responden yang menyatakan kurang sesuai. Untuk model busana cocktail kedua dapat disimpulkan bahwa $87 \%$ responden yang menyatakan sangat sesuai dan $13 \%$ responden yang menyatakan sesuai. Sedangkan untuk kategori tingkat kesesuaian 
warna dengan sumber ide untuk model busana cocktail pertama dapat disimpulkan bahwa $90 \%$ responden yang menyatakan sangat sesuai, $7 \%$ responden yang menyatakan sesuai, dan $3 \%$ responden yang menyatakan kurang sesuai dan untuk model busana cocktail kedua dapat disimpulkan bahwa 93\% responden yang menyatakan sangat sesuai dan $7 \%$ responden yang menyatakan sesuai.

\section{Saran}

Berdasarkan hasil penelitian maka:

1. Perlunya penelitian lebih lanjut mengenai proses tie- dye pada bahan satin dengan mengeksplore berbagai macam pewarna

2. Penelitian mengenai smock disesuaikan dengan tema

yang diambil

3. Pemasangan hiasan busana yang masih perlu di eksplore

\section{DAFTAR PUSTAKA}

Agustina, E., Mardiansyah, M. A., Doudi, M., \& Annas, S. (2016). Karakterisitik Spesies Karang Di Perairan Rinon Pulo Breubeuh. Prosiding Seminar Nasional Biotik, 43-48.

Alifah, A. (2018). Busana pesta Coctail dengan Sumber Ide Grebeg Selarong dalam Pagelaran Busana Movitsme (Issue Juli). Universitas Negeri Yogyakarta.

Arnold, R. (2001). Fashion, Desire and Anxiety: Image and Morality in The 20th Century. In I.B Tauris Publisher (First). I.B Tauris.
Elyssa da Cruz. (2004). Dressing for the Cocktail Hour | Essay | The Metropolitan Museum of Art | Heilbrunn

Timeline of Art History. Heilbrun Time Line of Art History. New York: The Metropolitan Museum of Art. https:// www.metmuseum.org/toah/hd/coho/ hd_coho

.htm

Gausa, S. (2015). Tie -Dye ( ADIRE ) Among The Jukun People. Mgbakoigba: Journal of African Studies, 4(November), 1-13.

Harsono, M. A. S. (2019). Desain Woman Luxury Party Wear Dengan Teknik Embroidery Ars Panicalensis. Jurnal Moda, 1(1), 15-24.

Hartini, H. (2017). Perkembangan Fisik Dan Body Image

Remaja. ISLAMIC COUNSELING: Jurnal Bimbingan Konseling Islam, 1(2), 27. https://doi.org/10.29240/jbk.v1i2.329

Hill, D. D. (2004). As Seen in Vogue: A Century of American Fashion in Advertising. In Texas tech

University Press (First). Texas tech University Press. Kurniawati, R. (2017). Busana Pesta Malam untuk Wanita dengan Sumber Ide Kuil Baalbek dalam Pagelaran

Busana "Dimantion." Universitas Negeri Yogyakarta. Ristiani, S., \& Irianti Nugrahani. (2014). Eksplorasi

Pewarnaan Teknik Smock Kombinasi Tritik 
MODA volume 3 Nomor 2 Juli 2021

Jumputan untuk Produk Fashion.

Majalah Ilmiah: Dinamika Kerajinan

Dan Batik, 31(2), 85-100.

St Aisyah. (2017). Identifikasi Kemampuan

Membuat Pola Busana Wanita Pada

Mahasiswa Jurusan PKK FT UNM.

Jurnal Systemik, 1(1), 225-231.

Steele, V. (2005). Encyclopedia of Clothing and Fashion.

In C. Breward, J. B. Eicher, J. S. Major, \& P. Tortora (Eds.), Thomson Gale (First). Thomson Gale.

Utami, N. R. (2018). Eksplorasi Teknik Smock Flower

Sebagai Aplikasi Pada P r o d u k Fashion. E-Proceeding of Art \& Design, 5(3), 2293-2316.

Wardoyo, S., \& Suryo Tri Widodo. (2018). Kreasi Motif

Pada Produk Tie-Dye (Ikat Celup) di Kota Yogyakarta. BP ISI Yogyakarta. 